\title{
Conservation Tillage Practices Optimizes Root Distribution and Straw Yield of Spring Wheat and Field Pea in Dry Areas
}

\author{
Stephen Yeboah ${ }^{1,2,4}$, Shirley Lamptey ${ }^{1,3,5}$, Renzhi Zhang ${ }^{1,2}$ \& LingLing $\operatorname{Li}^{1,3}$ \\ ${ }^{1}$ Gansu Provincial Key Lab of Aridland Crop Science, Gansu Agricultural University, Lanzhou, China \\ ${ }^{2}$ College of Resources and Environmental Sciences, Gansu Agricultural University, Lanzhou, China \\ ${ }^{3}$ College of Agronomy, Gansu Agricultural University, Lanzhou, China \\ ${ }^{4}$ CSIR-Crops Research Institute, Kumasi, Ghana \\ ${ }^{5}$ Department of Agronomy, University for Development Studies, Tamale, Ghana \\ Correspondence: Stephen Yeboah, Gansu Provincial Key Laboratory of Aridland Crop Science, Gansu \\ Agricultural University, Lanzhou, China. Tel: 86-136-3932-8274. E-mail: proyeboah@yahoo.co.uk
}

Received: February 12, 2017

Accepted: April 17, $2017 \quad$ Online Published: May 15, 2017

doi:10.5539/jas.v9n6p37

URL: https://doi.org/10.5539/jas.v9n6p37

\begin{abstract}
The objective of this study was to evaluate the effect of conventional tillage with straw removed (T), no tillage with straw removed (NT), no tillage with straw retained on the soil surface (NTS) and conventional tillage with straw incorporated (TS) on soil moisture, root growth and straw yield under rain-fed conditions. Findings of this research show that NTS and to a lesser extent, TS decreased soil bulk density in the $0-10 \mathrm{~cm}$ soil depth by approximately $3.35 \%$ and $2.75 \%$ compared to $\mathrm{T}$ and NT in spring wheat and field pea plots respectively. No tillage with straw retained (NTS) had greater soil moisture content $(0-30 \mathrm{~cm})$ at jointing, anthesis and milking stages compared with NT and T treatments with average $18.57 \%$ and $29.67 \%$ increase $(\mathrm{P}<0.05)$ in spring wheat and field pea respectively. Compared with $\mathrm{T}$ and NT, root length, root surface area, root diameter and root volume at $0-50 \mathrm{~cm}$ soil depth under straw treated soils, especially with no tillage were significantly increased. Root length, surface area and root diameter in the $0-80 \mathrm{~cm}$ differed among the treatments in the order of NTS > TS $>$ NT $>$ T at all the sampling stages in both crops. No tillage with straw retention had the greatest straw yield of $4897 \mathrm{~kg} \mathrm{ha}^{-1}$ in spring wheat and $2759 \mathrm{~kg} \mathrm{ha}^{-1}$ in field pea, representing a significant increase of $20.61 \%$ and $22.74 \%$ compared to NT and T respectively. These results suggest that NTS could enhance spring wheat and field pea yield and water uptake via stimulating root growth, and therefore a practical way to improve crop productivity.
\end{abstract}

Keywords: crop production, no tillage, root morphology, soil moisture

\section{Introduction}

The adoption of conservation agriculture principles as part of a change in management system has been reported to increase crop productivity and water conservation (Huang et al., 2008; Yeboah et al., 2016). It is claimed that conservation tillage can serve as an important management strategy offering many benefits like increasing organic matter content (Yeboah et al., 2016) and soil moisture (Hobbs, 2008) compared to tilled soils. The increase was attributed to the less physical disturbance that helps to maintain or conserve soil moisture. Tillage activity exposed more soil surface area to the atmosphere, providing a greater evaporative area and, consequently, a greater water loss (Govarts et al., 2007). Tillage practices with stubble retention and subsequent incorporation into the soil has gained interest amongst farmers in the Western Loess Plateau, which is practiced widely as a measure to mitigate impacts on soil, and for water conservation purposes (Huang et al., 2008).

Root development and distribution in the soil profile are of great importance for water and nutrient uptake for plants. Soil moisture and nutrient availability affect root growth, which has a significant impact on the spatial distribution of root systems (Smith et al., 2012). Root mass is significantly greater in wet soil than in dry soil (Verónica et al., 2011). Some of the practices such as tillage affect root development and function, which by far is the most important component in crop growth (Mosaddeghi et al., 2009). As with impact of tillage on root distribution, no-tillage causes greater and deeper water accumulation in the soil profile and greater root growth (Lampurlanés et al., 2001). Root growth in the subsoil can be affected by tillage (Mosaddeghi et al., 2009), 
which is the most important role that tillage plays in the soil-plant systems. The continuous use of conventional tillage practices can create hardpans in the subsoil, which can be detrimental to root proliferation below the plough layers (Karunatilake et al., 2000). Root morphology and spatial distribution are significantly affected by soil properties (Linkohr et al., 2002). A higher soil bulk density can decrease root length and trigger the formation of lateral roots (Ball Coelho et al., 1998). Reductions in soil resources and increases in soil bulk density significantly influence root growth and distribution, and reduce soil moisture and nutrient absorption by roots (Carole et al., 2012). High soil compaction has recently been identified as the main limiting factor for plant root growth and uptake of moisture (Zheng \& Yan, 2006). The spatial distribution of soil moisture and nutrients is affected by soil properties and the spatial distribution of roots $(\mathrm{Li}, 2008)$. Therefore, the coordination of root system distribution, and available soil moisture in the soil profile, are required for optimal plant growth and production (Vanessa et al., 2013).

Although many studies have been conducted on the effects of conservation tillage systems on soil conditions, root growth and crop yields under various soil and climatic conditions in different countries, little research has focused on the influence of tillage practices on yield, soil moisture and root growth in spring wheat-field pea rotation under rain-fed semi-arid Northwest of China. This study aimed to determine the response of spring wheat and field pea straw yield, root growth (root length, root surface area and root diameter) and soil moisture to tillage practices under rain-fed conditions.

\section{Materials and Methods}

\subsection{Site Description}

The field experiments was conducted in 2016 growing seasons under rainfed conditions at the Dingxi Experimental Station $\left(35^{\circ} 28^{\prime} \mathrm{N}, 104^{\circ} 44^{\prime} \mathrm{E}\right.$ and elevation $\left.1971 \mathrm{~m}\right)$, Gansu Province, northwestern China. The initial 0-200 cm soil layer has a $\mathrm{pH}$ of 8.45 , soil bulk density was $1.17 \mathrm{~g} \mathrm{~cm}^{-3}$, soil organic matter was $16.04 \mathrm{~g}$ $\mathrm{kg}^{-1}$, available nitrogen was $51.10 \mathrm{mg} \mathrm{kg}^{-1}$, available phosphorus was $21.19 \mathrm{mg} \mathrm{kg}^{-1}$, available potassium was $100.9 \mathrm{mg} \mathrm{kg}^{-1}$, total nitrogen was $0.86 \mathrm{~g} \mathrm{~kg}^{-1}$, total phosphorus was $0.82 \mathrm{~g} \mathrm{~kg}^{-1}$, total potassium was $28.00 \mathrm{~g} \mathrm{~kg}^{-1}$, and wilting point and saturated water content was $7.3 \%$ and $21.9 \%$ respectively. The Long-term annual rainfall at the experimental site averages $391 \mathrm{~mm}$ ranging from $246 \mathrm{~mm}$ in 1986 to $564 \mathrm{~mm}$ in 2003 . Annual accumulated temperature $>10{ }^{\circ} \mathrm{C}$ is $2239^{\circ} \mathrm{C}$. The site had a long history of continuous cropping using conventional tillage. The crop prior to the experiment commencement in 2001 was flax (Linum usitatissimum L.). Total rainfall recorded during the course of the study was $239 \mathrm{~mm}$.

\subsection{Experimental Design and Treatment Description}

The experiment utilized randomized complete block design, 2 phases, replicated 4 times (blocks). Spring wheat (cv. Dingxi No. 35) and field pea (cv. Yannong) were sown in rotation in both phases represented in each year. Phase 1 started with spring wheat, followed by field pea (referred to Wheat-Pea-Wheat) and phase 2 started with field pea, followed by spring wheat (referred to Pea-Wheat-Pea) sequence. Therefore, there were 48 plots in total. Plots were $4 \mathrm{~m}$ wide $\times 17 \mathrm{~m}$ long in block $1,21 \mathrm{~m}$ long in blocks 2 and 3 and $20 \mathrm{~m}$ long in block 4 . The treatments were, Conventional tillage with straw removed (T): seedbed preparation of this treatment included moldboard ploughing immediately after harvesting the previous crop (July-August), with a second ploughing prior to sowing in spring (March-April), all to a depth of 10-20 cm. Harrowing was carried out prior to sowing in spring, and then sown by no-till seeder. All stubble was removed before cultivation. This represents the typical tillage practice in the Western Loess Plateau; No-till with stubble removed (NT): no cultivation was performed throughout the season in this treatment. The crops were sown with no-till seeder. All the stubble was removed at crop harvest; No-till with straw retained (NTS): no cultivation was performed throughout the season. All the stubble from the previous crop was returned to the original plot on the soil surface without incorporation. Chopped wheat straw was used and the crops were sown with the no-till seeder; Conventional tillage with stubble incorporated (TS): cultivation was the same as treatment for $\mathrm{T}$, however all stubble from the previous crop was returned to the original plot immediately after threshing and then incorporated into the soil with the first cultivation. The crops were sown with the no-till seeder.

\subsection{Soil Moisture}

A 2-m long aluminium access tube was installed in each plot for measurement of soil moisture content. Soil moisture content $\left(\mathrm{cm} \mathrm{cm}^{-3}\right)$ was measured using a Trime-Pico IPH (Precise Soil Moisture Measurement, IMKO Micromodultechnik GmbH, Ettlingen, Germany) at jointing, anthesis and milking in 10-30, 30-50, 50-80, 80-110 $\mathrm{cm}$. Trime-Pico measures volumetric soil water content in 10-110 $\mathrm{cm}$ depth intervals described above. The soil moisture contents in 0-5 and 5-10 cm were measured gravimetrically. Gravimetric water content (0-5 and 5-10 $\mathrm{cm}$ ) was multiplied by soil bulk density to obtain the volumetric water content. 


\subsection{Soil Bulk Density}

Soil bulk density (BD) was determined using the beveled stainless steel ring method (Carter, 1993). The measurement was conducted in 0-5, 5-10 and 10-30 cm soil layers.

\subsection{Root Sampling}

Roots were sampled at jointing, anthesis and milking stages by taking soil cores at $0-10,10-30$ and 30-50 and $50-80 \mathrm{~cm}$ depending on stage and crop. Each treatment was sampled by collecting soil cores with a hand-held auger ( $8 \mathrm{~cm}$ diameter) at three separate locations avoiding wheel traffic: (i) within the row, (ii) between the rows, and (iii) in an intermediate position, i.e., with one edge of the core touching the row. Three locations were chosen because it was reported that the root distribution in the row was different from that in the mid-row (Rubino and Franchi, 1990). Following sampling, soil cores from the same depth in each plot were pooled to form one composite sample, and the roots were washed within half hour by swirling water through nylon netting (400 holes $\mathrm{cm}^{-2}$ ) from the soil. Debris and other extraneous materials were removed from the root samples using tweezers. Root image from each core was obtained using a scanner (Epson V700, Indonesia). The images were analyzed using the software WinRHIZO version 5.0 (Regent Instruments Inc., Quebec City, Canada).

\subsection{Straw Yield $\left(\mathrm{kg} \mathrm{ha}^{-1}\right)$}

At maturity spring wheat and field pea were harvested manually using sickles to cut plants at $5 \mathrm{~cm}$ above ground level. The edges $(0.5 \mathrm{~m})$ of the plot were trimmed and discarded. The above ground straw yield were determined on dry weight basis by oven-drying at $105^{\circ} \mathrm{C}$ for $45 \mathrm{~min}$ and then dried to constant weight at $85^{\circ} \mathrm{C}$.

\subsection{Statistical Analyses}

Data were analyzed using Statistical Package for the Social Sciences (SPSS software, 22.0, USA). Differences among treatment means were compared using Least Significant Difference (LSD). Significances were declared at the probability level of 0.05 .

\section{Results}

\subsection{Soil Moisture}

Soil moisture content $\left(\mathrm{cm} \mathrm{cm}^{-3}\right)$ measured at jointing, anthesis and milking stages increased with increasing soil depth regardless of treatments (Figure 1). Significant differences $(\mathrm{P}<0.05)$ in soil moisture were only observed in some depth intervals, as shown in Figure 1. There was significantly higher soil moisture contents in the no tillage with straw retention (NTS) compared with conventional tillage with straw removed (T) and to a lesser extent no tillage with straw removed (NT) treatment, particularly in the $0-30 \mathrm{~cm}$ depth interval. These observations were fairly consistent for both crops. Significant differences $(\mathrm{P}<0.05)$ in soil moisture content were larger in 0-30 cm depth interval. In the upper $30 \mathrm{~cm}$ soil depth, NTS obtained the highest soil moisture content of $14.55 \mathrm{~cm} \mathrm{~cm}^{-3}$, or $26.07 \%$ and $15.60 \%$ compared to $\mathrm{T}\left(11.54 \mathrm{~cm} \mathrm{~cm}^{-3}\right)$ and NT $\left(12.59 \mathrm{~cm} \mathrm{~cm}^{-3}\right)$ at jointing in spring wheat. Also, at anthesis in spring wheat, soil moisture content in the 0-30 cm was higher in NTS $\left(11.47 \mathrm{~cm} \mathrm{~cm}^{-3}\right)$, followed by NT $\left(10.52 \mathrm{~cm} \mathrm{~cm}^{-3}\right)$ and TS $\left(10.14 \mathrm{~cm} \mathrm{~cm}^{-3}\right)$ and the least in T $\left(9.21 \mathrm{~cm} \mathrm{~cm}^{-3}\right)$. Similarly at milking, soil moisture content in the spring wheat plots were higher in NTS $\left(11.25 \mathrm{~cm} \mathrm{~cm}^{-3}\right)$, followed by TS $\left(10.56 \mathrm{~cm} \mathrm{~cm}^{-3}\right)$ and NT $\left(8.99 \mathrm{~cm} \mathrm{~cm}^{-3}\right)$ and the least in $\mathrm{T}\left(7.60 \mathrm{~cm} \mathrm{~cm}^{-3}\right)$. A similar trend of soil moisture content was observed in field pea plots, where NTS consistently recorded the highest soil moisture content. The result was clear that, the soil moisture content was higher on straw amended plots and the moisture content generally decreased with increasing plant growth. Moreover, the treatment effects on soil moisture in the 30 to $110 \mathrm{~cm}$ soil depths followed a similar trend as those in the 0 to $30 \mathrm{~cm}$. 


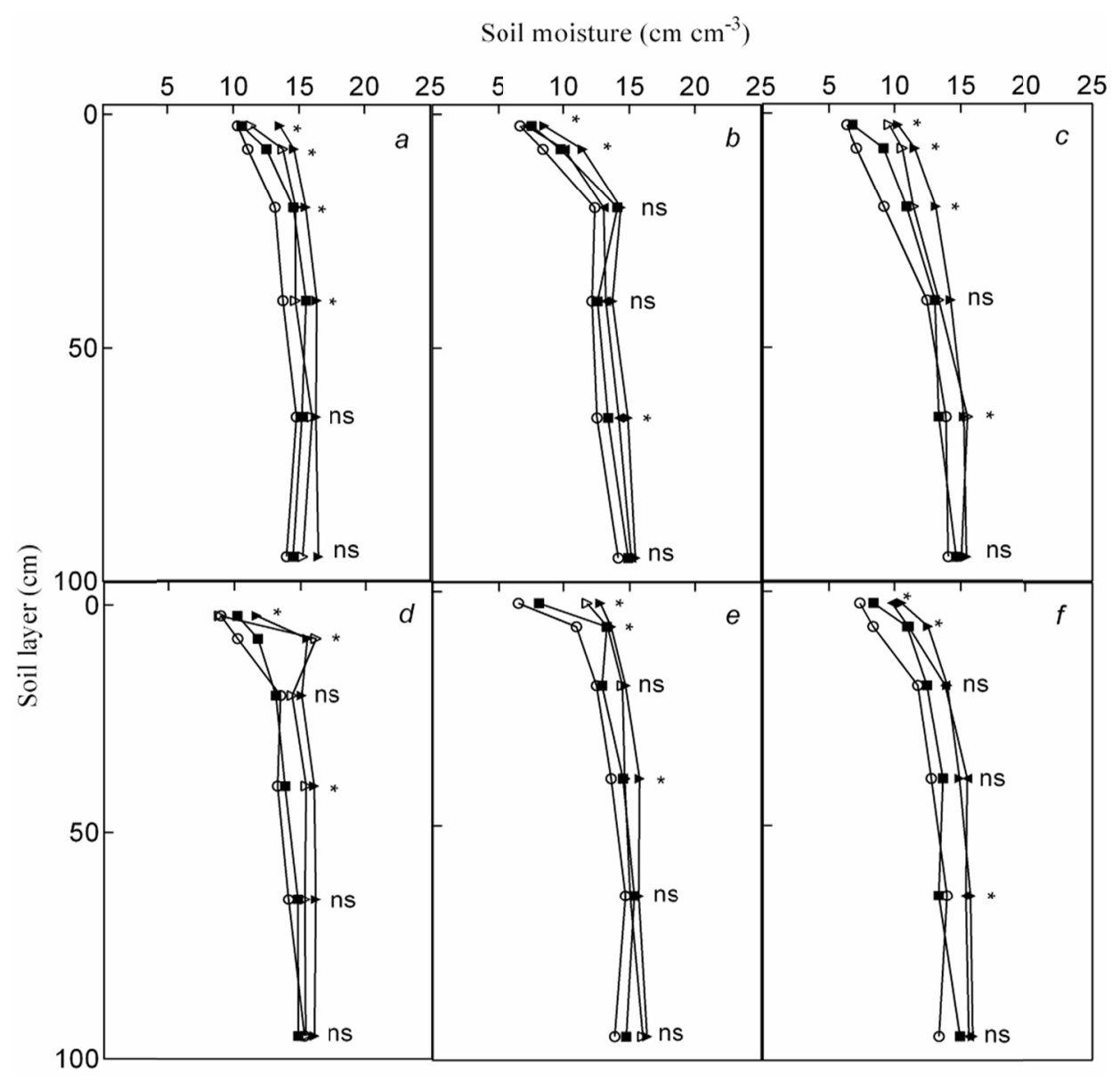

Figure 1. Soil moisture content at the $0-110 \mathrm{~cm}$ depth range recorded at jointing, anthesis and milking in spring wheat $(A-C)$, and field pea $(D-F)$, respectively

Note. Symbols are: (o) T; $(\boldsymbol{\bullet}) \mathrm{NT} ;(\boldsymbol{\Delta}) \mathrm{NTS} ;(\Delta)$ TS. Mean values $\pm \mathrm{SE}(\mathrm{n}=3)$, and means comparison based on least significant difference $(\mathrm{P}<0.05)$. Significance $(\mathrm{P}<0.05)$ is indicated with an asterisk.

\subsection{Soil Bulk Density}

Significant differences $(\mathrm{P}<0.05)$ in soil bulk density in different soil layers and treatments were observed in this study (Table 1). The soil bulk density increased with increasing soil depth; therefore the bulk density was without exception the highest in 10-30 cm and the lowest in $0-5 \mathrm{~cm}$ soil layer. Results showed lower bulk density in NTS $\left(1.17 \mathrm{~g} \mathrm{~cm}^{-3}\right)$ than that of $\mathrm{T}\left(1.23 \mathrm{~g} \mathrm{~cm}^{-3}\right)$ in the $0-5 \mathrm{~cm}$ soil depth in spring wheat plots. In addition, at $5-10 \mathrm{~cm}$ the soil bulk density was significantly decreased $(\mathrm{P}<0.05)$ in NTS by $4.83 \%$ compared to NT soils. In the field pea plots, significant differences $(\mathrm{P}<0.05)$ were found only in the $0-5 \mathrm{~cm}$, where NTS had the lowest bulk density of $1.15 \mathrm{~g} \mathrm{~cm}^{-3}$. This represent a significant increase of $4.68 \%$ compared to T soils $\left(1.20 \mathrm{~g} \mathrm{~cm}^{-3}\right)$. At the deeper soil layers $(10-30 \mathrm{~cm})$ differences between the treatments were small and the result was clear that, the contribution to decrease soil bulk density was much higher under straw application soils than those of non-straw amended soils in both crops. 
Table 1. Soil bulk density in spring wheat and field pea as affected by treatment

\begin{tabular}{|c|c|c|c|c|c|c|}
\hline \multirow{3}{*}{ Treatment } & \multicolumn{6}{|c|}{ Soil bulk density $\left(\mathrm{g} \mathrm{cm}^{3}\right)$} \\
\hline & \multicolumn{3}{|c|}{ Spring wheat } & \multicolumn{3}{|c|}{ Field pea } \\
\hline & $0-5 \mathrm{~cm}$ & $5-10 \mathrm{~cm}$ & $10-30 \mathrm{~cm}$ & $0-5 \mathrm{~cm}$ & $5-10 \mathrm{~cm}$ & $10-30 \mathrm{~cm}$ \\
\hline $\mathrm{T}$ & 1.23 & 1.26 & 1.31 & 1.20 & 1.24 & 1.29 \\
\hline NT & 1.21 & 1.30 & 1.30 & 1.18 & 1.27 & 1.28 \\
\hline NTS & 1.17 & 1.24 & 1.28 & 1.15 & 1.21 & 1.27 \\
\hline TS & 1.18 & 1.26 & 1.30 & 1.17 & 1.23 & 1.28 \\
\hline LSD (0.05) & 0.031 & 0.012 & 0.047 & 0.017 & 0.023 & 0.027 \\
\hline
\end{tabular}

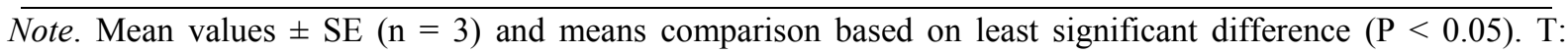
conventional tillage with straw removed; NT: no-tillage with straw removed; NTS: no-tillage with straw retained; TS: conventional tillage with straw incorporated.

\subsection{Root Morphological Characteristics}

\subsubsection{Root Length}

Application of no tillage with straw retention (NTS) practices had significant effect on root morphology, especially at the 0-10 and 10-30 cm depth intervals (Figure 2). Significant differences $(\mathrm{P}<0.05)$ in root length were only observed in some depth intervals, as shown in Figure 2 . The root length was highest in the $0-10 \mathrm{~cm}$ at jointing and $10-30 \mathrm{~cm}$ at anthesis and milking both crops. In spring wheat plots, the total root length in $0-50 \mathrm{~cm}$ soil under NTS treatment increased by $35.01 \%$ and $35.76 \%$ (jointing), $23.79 \%$ and $53.87 \%$ (anthesis), and $20.55 \%$ and $64.29 \%$ (milking) compared to NT and T plots. Similarly, values in field pea plots were, respectively, $10.69 \%$ and $19.67 \%$ compared to NT and T soils in the $0-30 \mathrm{~cm}$. Conventional tillage with straw incorporated (TS) also had higher root length relative to T soils, but differences were not always significant at $\mathrm{P}$ $<0.05$. The root length in the $50-80 \mathrm{~cm}$ in spring wheat was greater in NTS $(939.42 \mathrm{~cm} ; 517.24 \mathrm{~cm})$ at anthesis and milking respectively. This represented an increase of $88.20 \%$ and $69.14 \%$ at anthesis and $79.83 \%$ and $48.77 \%$ at milking versus NT and T treatments respectively. 


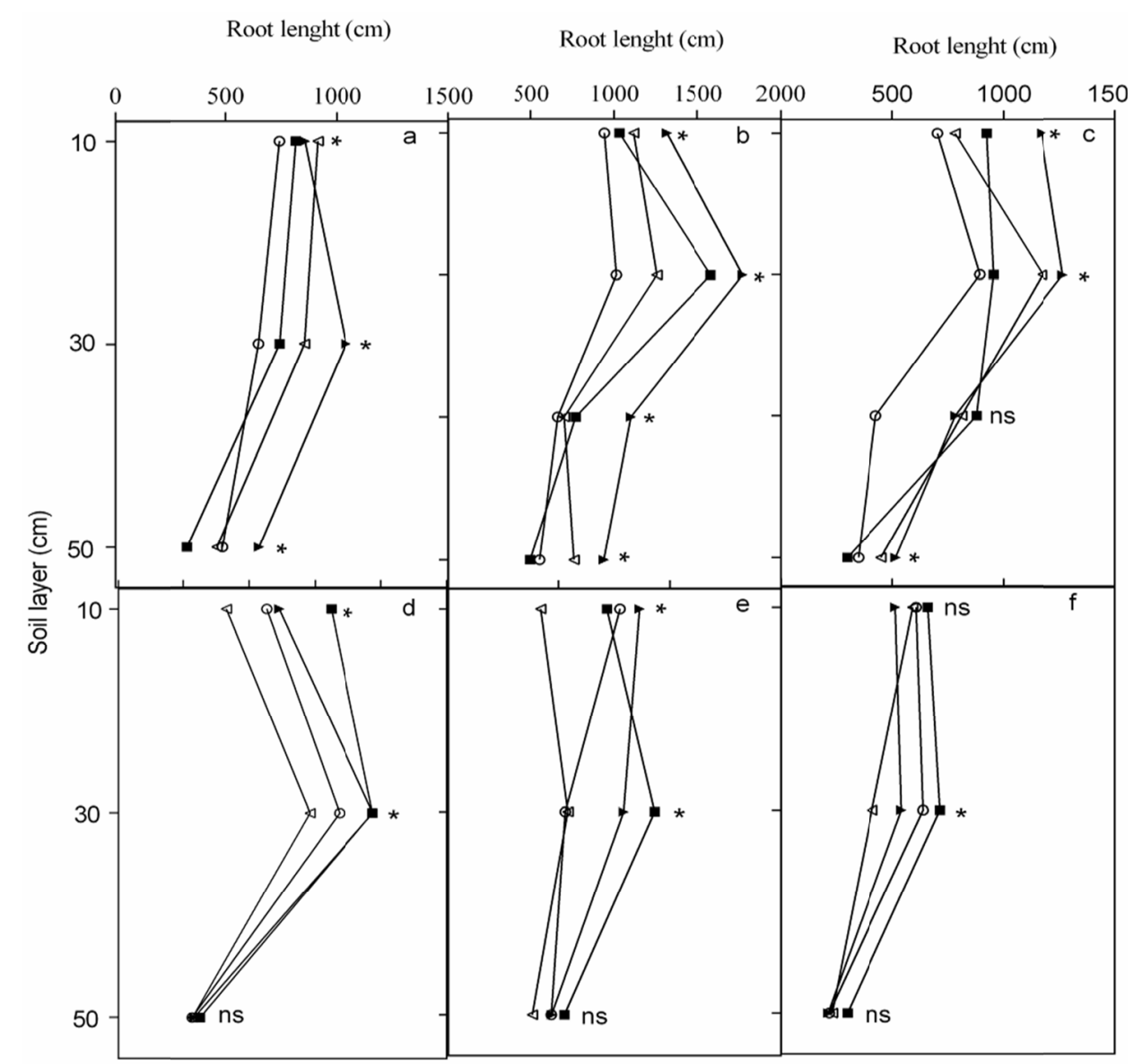

Figure 2. Root length recorded at jointing, anthesis and milking in spring wheat $(A-C)$, and field pea $(D-F)$, respectively

Note. Symbols are: (o) T; $(\boldsymbol{\bullet}) \mathrm{NT} ;(\boldsymbol{\Delta}) \mathrm{NTS} ;(\Delta) \mathrm{TS}$. Mean values $\pm \mathrm{SE}(\mathrm{n}=3)$, and means comparison based on least significant difference $(\mathrm{P}<0.05)$. Significance $(\mathrm{P}<0.05)$ is indicated with an asterisk.

\subsubsection{Root Surface Area}

The maximum root surface area was recorded in the $0-10 \mathrm{~cm}$ at jointing and $10-30 \mathrm{~cm}$ soil layer at anthesis and milking in both spring wheat and field pea under NTS treatment and was significantly greater than those in $\mathrm{T}$ and NT treatments (Figure 3). There were significant differences $(\mathrm{P}<0.05)$ at certain depths in root surface area as indicated in Figure 3. Root surface area decreased with increasing depth under all treatments. For example, the root surface area in the $0-50 \mathrm{~cm}$ soil layer under NTS in spring wheat accounted for about $37.23 \%$ and $51.85 \%$ of total root surface area and this was significantly greater that those under NT and T soils. Moreover, the root surface area in field pea was higher under NTS at jointing $\left(180.81 \mathrm{~cm}^{2}\right)$, at anthesis $\left(268.88 \mathrm{~cm}^{2}\right)$ and at milking $\left(179.95 \mathrm{~cm}^{2}\right)$ compared to $\mathrm{T}\left(139.53,194.77\right.$ and $\left.118.51 \mathrm{~cm}^{2}\right)$, respectively. The root surface area was greater in the straw amended soils compared to the non-straw amended soils. Significant differences were found among the conventional tillage with straw incorporated (TS) and conventional tillage with straw removed (T) in most instances of sampling at $\mathrm{P}<0.05$. 


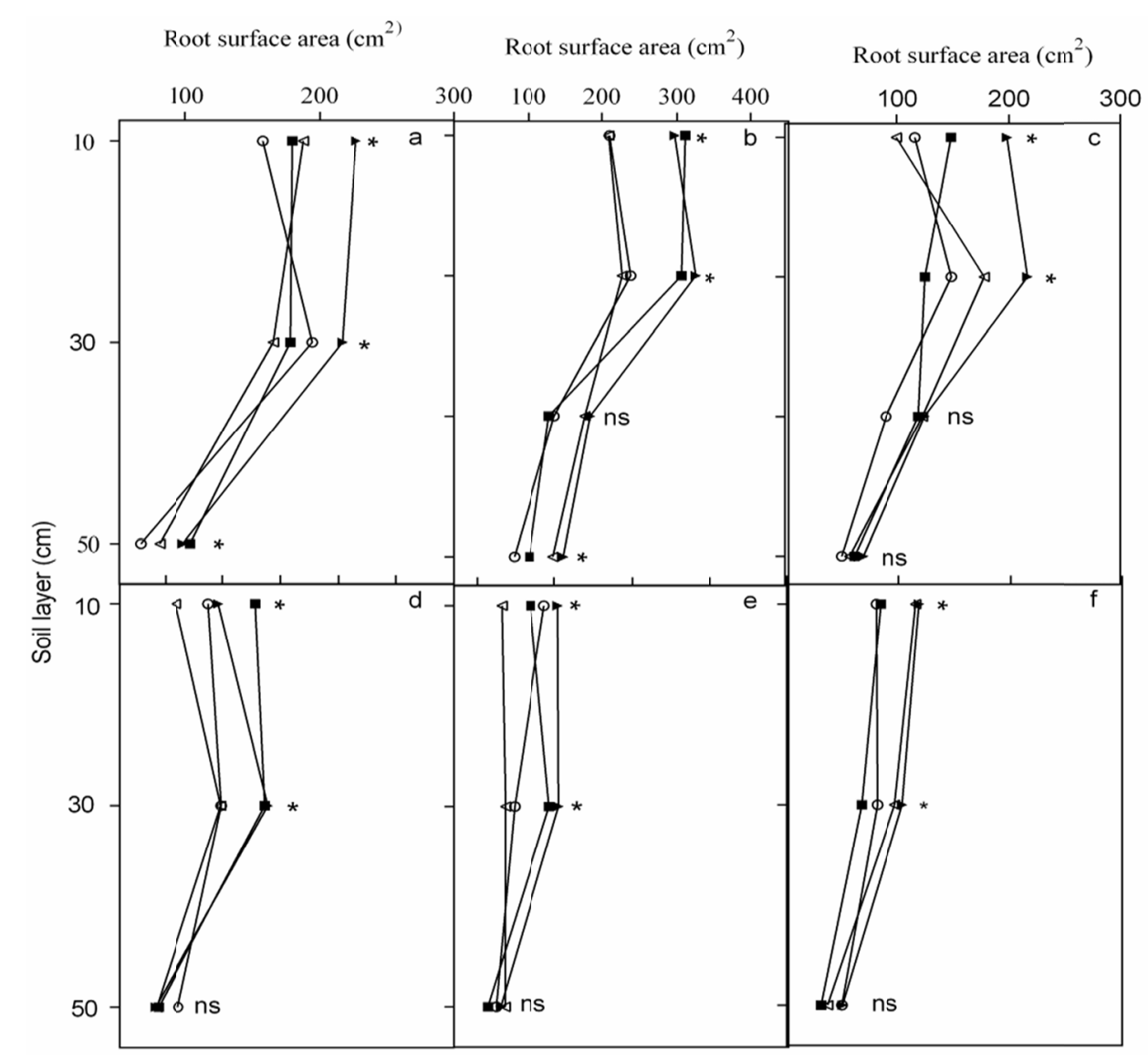

Figure 3. Root surface area recorded at jointing, anthesis and milking in spring wheat $(A-C)$, and field pea $(D-F)$, respectively

Note. Symbols are: (o) T; $(\boldsymbol{\bullet}) \mathrm{NT} ;(\boldsymbol{\Delta}) \mathrm{NTS} ;(\Delta) \mathrm{TS}$. Mean values $\pm \mathrm{SE}(\mathrm{n}=3)$, and means comparison based on least significant difference $(\mathrm{P}<0.05)$. Significance $(P<0.05)$ is indicated with an asterisk.

\subsubsection{Root Diameter}

The trend of proportions of root diameter in different soil layers and treatments was consistent with those for root length and root surface area (Figure 4). The proportion of root diameter in the top soil layer $(0-30 \mathrm{~cm})$ was higher $(0.62 \mathrm{~mm})$ than deeper soil layer $(0.47 \mathrm{~mm})$ in spring wheat. Similar values in field pea were $0.57 \mathrm{~mm}$ in top soil layer $(0-30 \mathrm{~cm})$ and $0.49 \mathrm{~mm}$ in deeper soil layer $(30-50 \mathrm{~cm})$. A consistent result were achieved in that, NTS significantly increased $(\mathrm{P}<0.05)$ root diameter between $14.55-23.63 \%$ and $4.03-10.45 \%$ in spring wheat compared with T and NT treatments at $0-30 \mathrm{~cm}$. In field pea plots, NTS and TS caused a significant increase in root diameter by approximately $4.23 \%$ compared to $\mathrm{T}$. Treatment effect between NT and T were not significantly different $(\mathrm{P}<0.05)$ in all the stages of sampling. 


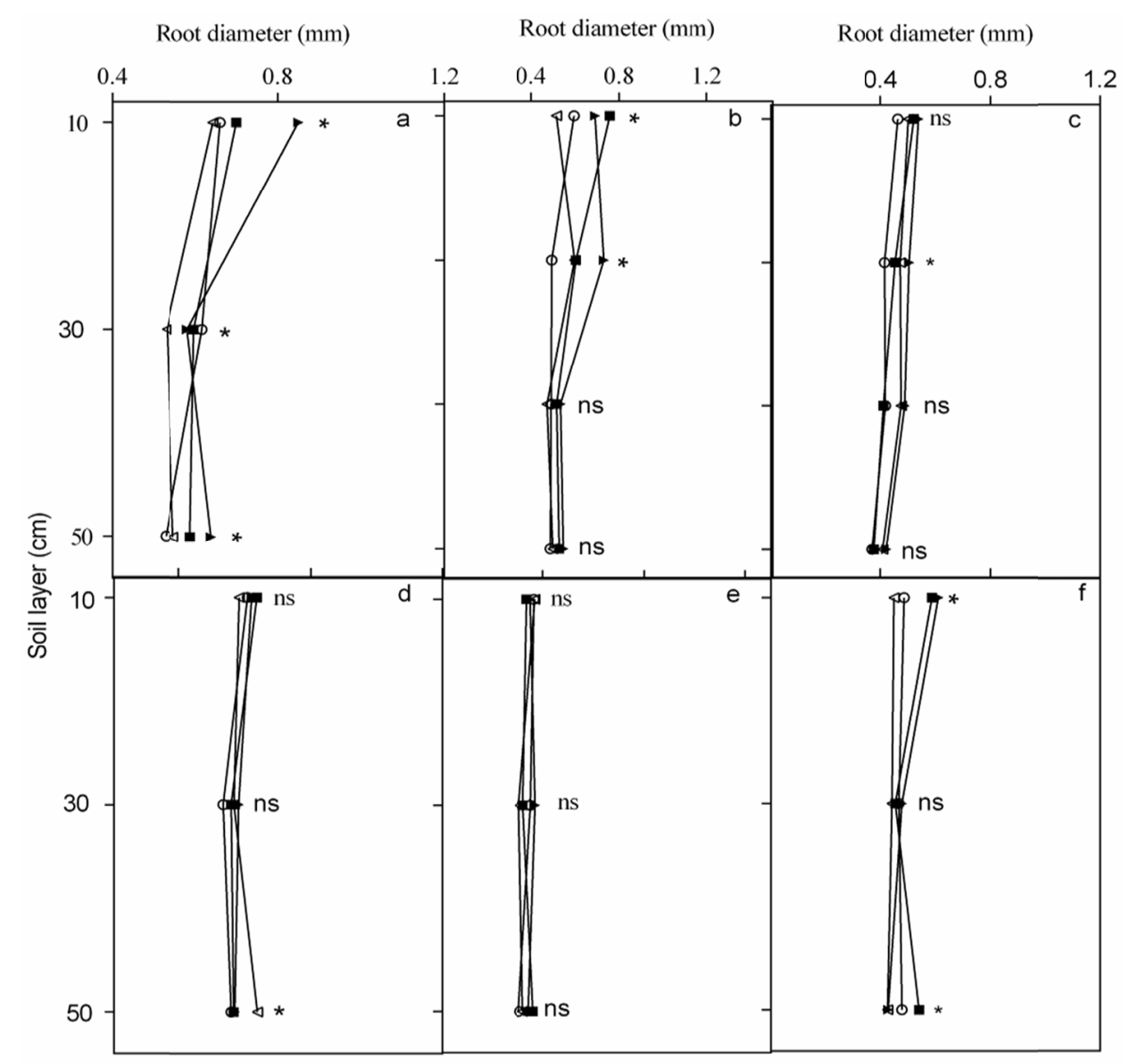

Figure 4. Root diameter recorded at jointing, anthesis and milking in spring wheat $(A-C)$, and field pea $(D-F)$, respectively

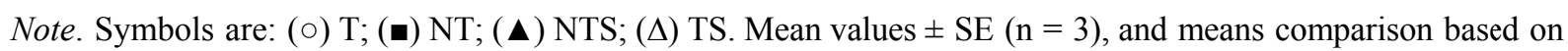
least significant difference $(P<0.05)$. Significance $(\mathrm{P}<0.05)$ is indicated with an asterisk.

\subsubsection{Root Volume}

Overall, there were significant treatments differences in root volume, which were observed in both spring wheat and field pea. In the spring wheat plot, NTS had the greatest root volume at jointing $\left(3.19 \mathrm{~cm}^{3}\right)$, anthesis $(4.34$ $\left.\mathrm{cm}^{3}\right)$ and milking $\left(2.35 \mathrm{~cm}^{3}\right)$ in the $0-50 \mathrm{~cm}$ (Figure 5). This was followed by NT at jointing $\left(2.31 \mathrm{~cm}^{3}\right)$, anthesis $\left(4.01 \mathrm{~cm}^{3}\right)$ and milking $\left(1.79 \mathrm{~cm}^{3}\right)$. Similarly, in the field pea plots, the greatest root volume at jointing, anthesis and milking were observed in NTS $\left(1.94 \mathrm{~cm}^{3}\right)$, TS $\left(1.78 \mathrm{~cm}^{3}\right)$ and NT $\left(1.15 \mathrm{~cm}^{3}\right)$ respectively. The proportion of root volume in the $10-30 \mathrm{~cm}$ was the greatest $\left(3.37 \mathrm{~cm}^{3}\right)$, followed by $0-10 \mathrm{~cm}\left(2.34 \mathrm{~cm}^{3}\right)$ and then $30-50 \mathrm{~cm}$ $\left(1.75 \mathrm{~cm}^{3}\right)$ in the spring wheat crop. A similar trend was observed in the field pea plots; the greatest proportion of root volume was recorded in the $10-30 \mathrm{~cm}\left(1.45 \mathrm{~cm}^{3}\right)$, followed by $0-10 \mathrm{~cm}\left(1.39 \mathrm{~cm}^{3}\right)$ and the least in $30-50 \mathrm{~cm}$ $\left(0.97 \mathrm{~cm}^{3}\right)$. 


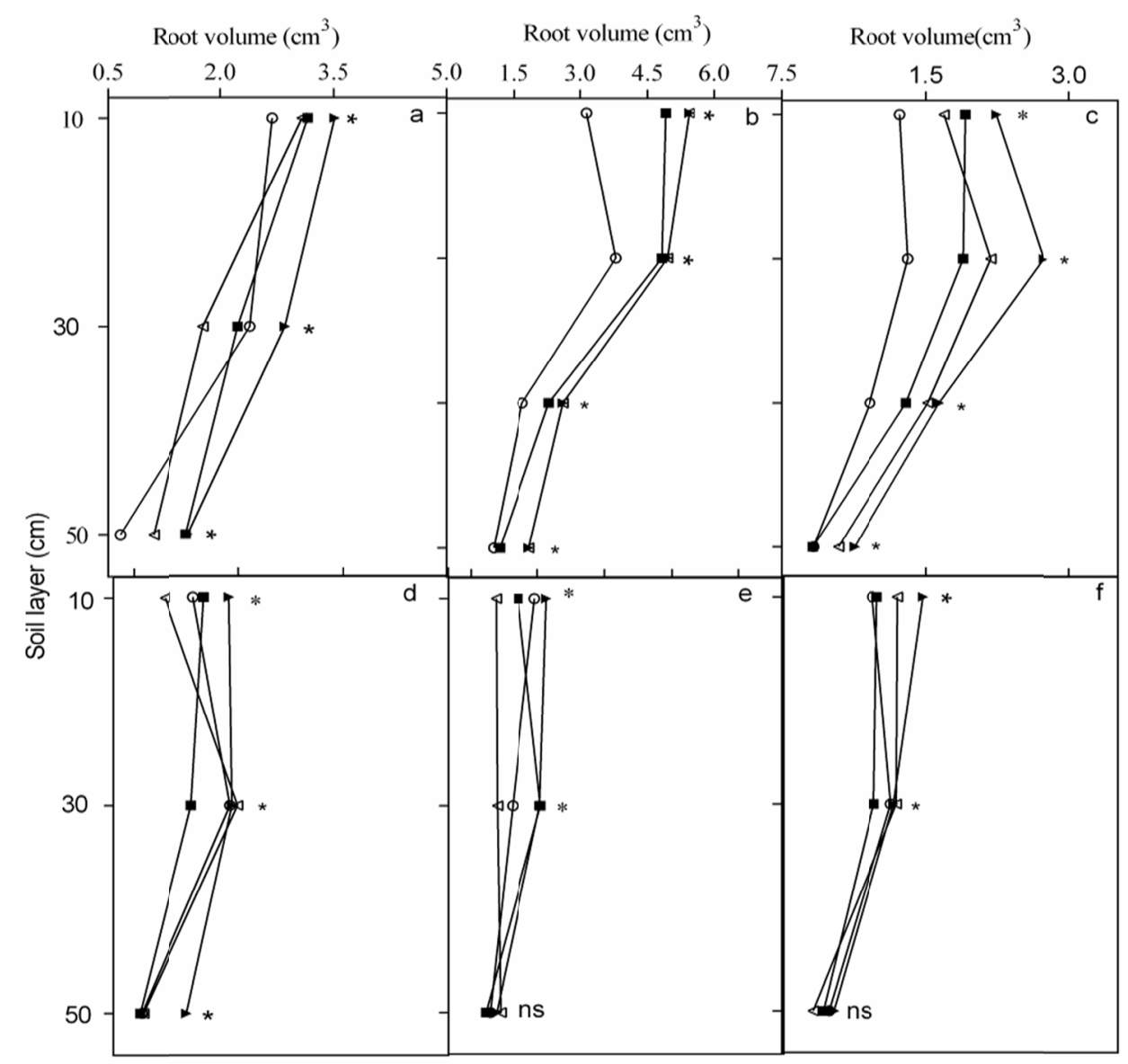

Figure 5. Root volume recorded at jointing, anthesis and milking in spring wheat $(A-C)$, and field pea $(D-F)$, respectively


least significant difference $(P<0.05)$. Significance $(\mathrm{P}<0.05)$ is indicated with an asterisk.

\subsection{Straw Yield}

Significant differences $(\mathrm{P}<0.05)$ among treatments were observed in straw yield in both spring wheat and field pea (Table 2). Application of no tillage with straw retention (NTS) practices increased straw yield in spring wheat by $21.64 \%$ and $19.58 \%$ compared to no till with straw removal (NT) and conventional tillage with straw removal (TS) respectively. There were no differences in straw yield of spring wheat between TS, and NT and T treatments. Similarly, in field pea plots, NTS had the highest straw yield of $2759 \mathrm{~kg} \mathrm{ha}^{-1}$, which represent a significant increase of $26.26 \%$ and $19.22 \%$ relative to $\mathrm{T}$ and NT respectively. In addition, TS practices also boosted straw yield in field pea by $22.66 \%$ in T and $15.82 \%$ in NT soils. Straw yield in both spring wheat and field pea was higher under NTS compared with TS, but the differences were not significant. 
Table 2. Straw yield in spring wheat and field pea as affected by treatment

\begin{tabular}{llc}
\hline \multirow{2}{*}{ Treatment } & \multicolumn{2}{c}{${\text { Straw yield }\left(\mathrm{kg} \mathrm{ha}^{-1}\right)}^{-1}$} \\
\cline { 2 - 3 } & Spring wheat & Field pea \\
\hline T & 4095 & 2185 \\
NT & 4026 & 2315 \\
NTS & 4897 & 2759 \\
TS & 4151 & 2681 \\
LSD (0.05) & $\mathbf{4 9 5 . 6 9}$ & $\mathbf{7 8 . 7 9}$ \\
\hline
\end{tabular}

Note. Mean values $\pm \mathrm{SE}(\mathrm{n}=3)$ and means comparison based on least significant difference $(\mathrm{P}<0.05)$. T: conventional tillage with straw removed; NT: no-tillage with straw removed; NTS: no-tillage with straw retained; TS: conventional tillage with straw incorporated.

\section{Discussion}

Root growth and development are critical for crops consumptive use of water and subsequent yield under water-limited conditions (Fageria, 2004; Bengough et al., 2011). Many previous studies have reported that the spatial distribution of roots is significantly influenced by soil tillage (e.g., Mosaddeghi et al., 2009). The findings of this study showed that no tillage with straw retention significantly decreased soil bulk density and boosted soil moisture content compared to conventional tillage with straw removed and no tillage with straw removed at the top soil depth $(0-30 \mathrm{~cm})$, and significantly affected the root length, root surface area, root diameter and root volume through the $0-50 \mathrm{~cm}$ soil profile. Many studies have demonstrated that excessive soil tillage increases soil bulk density (Fabrizzi et al., 2005; Yeboah et al., 2016), and reduces soil moisture (He et al., 2009; Yeboah et al., 2017). Long-term no tillage treatments has been reported to decreased soil bulk density in the surface layer (Yeboah et al., 2016) and that explained it as a direct consequence to the mulch layer on top of NT soils that provide soil organic matter. The increased soil moisture content under no-till and tillage treatments with straw application could be related to the straw mulch effect on the soil surface. The result was in agreement with Hobbs (2008), who found that no tillage with residue retention generally had higher surface soil water contents compared to tilled soils. This pattern indicates that tillage systems that involve less physical disturbance help to maintain or conserve soil moisture. The tillage activity exposed more soil surface area to the atmosphere, providing a greater evaporative area and, consequently, a greater water loss.

The increased in root morphological characteristics (root length, root surface area, root diameter and root volume) under straw amended soils, particularly in no tillage system up to $50 \mathrm{~cm}$ soil depth could largely be attributed to the decreased soil bulk density and the enhanced soil moisture, which promotes root proliferation during the growing season. At almost every growth stage, the root morphological characteristics in the top $50 \mathrm{~cm}$ soil depth under no tillage with straw retention was significantly greater than that under the no-tillage and conventional tillage with straw removed treatment. Other researchers have found root to be greater in the upper soil layer under no tillage system due to greater availability of water and nutrients (Muñoz-Romero et al., 2010). The root growth patterns under straw removal treatments were similar because of their similar soil conditions. Root length and root surface area are important parameters for characterizing root systems (Doussan et al., 2006).

The improved soil moisture content and root growth as a result of straw application increased straw yield in the no tillage (NTS) and at a lesser extent in the conventional tillage (TS) treatment. There was a direct and significant relation between the soil quality status and the crop yield, and no tillage with crop residue retention showed the highest crop yields as well as the highest soil quality status (Yeboah et al., 2016). Previous researches have shown that conservation tillage can improve crop yields (Huang et al., 2008, 2012; Yeboah et al., 2016). Differences in yield were mainly ascribed to increases in soil water content and rooting system, and reduction in soil bulk density. The integrated of these factors might have caused the higher straw yield observed in NTS and to a lesser extent the TS treatment. A possible explanation was that these treatments promotes wheat growth by storing sufficient water for plant use and providing lower bulk density soil for roots to penetrate and reach the deeper soil water. In the Mexican highlands, improved high-yielding wheat varieties yielded double under conservation agriculture compared to the farmer practice or zero tillage with residue removal, all with the same fertilizer inputs (Govaerts et al., 2007). Deeper and longer roots, and higher root surface area, diameter and volume, led to a greater uptake of deep soil moisture by the root system lower in the soil profile. Consequently, the improved root system led to greater straw yield from NTS, compared to NT and T. 


\section{Conclusion}

Finding of this research indicate that tillage practices such as no tillage with straw retained (NTS) and to a lesser extent conventional tillage with straw incorporated (TS) significantly enhanced soil moisture content and root growth, and decrease soil bulk density which led to greater straw yield. The tillage practices influenced soil bulk density and soil moisture, especially in the top plough layer $(0-10 \mathrm{~cm})$, where NTS and TS decreased soil bulk density as well as increase soil moisture content. Thus, greater root length, root surface area, root diameter and root volume were observed under the straw amended plots, especially with no tillage as compared to NT and T across the entire soil profile $(0-80 \mathrm{~cm})$ at jointing, anthesis and milking stage. These results indicate that no tillage with straw retention can be a feasible tillage practice for spring wheat and field pea production to alleviating food security issues currently experienced in the environment-damaged and water-shortage areas.

\section{References}

Ball-Coeho, B. R., Roy, R. C., \& Swanton, C. J. (1998). Tillage alters corn root distribution in coarse-textured soil. Soil Tillage Research, 53, 41-47.

Bengough, A. G., McKenzie, B. M., Hallett, P. D., \& Valentine, T. A. (2011). Root elongation, water stress, and mechanical impedance: A review of limiting stresses and beneficial root tip traits. Journal Experimental Botany, 62, 59-68. https://doi.org/10.1093/jxb/erq350

Carole, B., Gilles, V., \& Loic, P. (2012). Soil penetration resistance, a suitable soil property to account for variations in root elongation and branching. Plant Soil, 35, 169-180.

Carter, M. R. (1993). Soil sampling and methods of analysis. Canadian Journal of Soil Science (p. 823). Lewis Publisher London.

Doussan, C., Pierret, A., Garrigues, E., \& Pagès, L. (2006). Water uptake by plant roots: II-modelling of water transfer in the soil root-system with explicit account of flow within the root system-comparison with experiments. Plant Soil, 283, 99-117. https://doi.org/10.1007/s11104-004-7904-z

Fabrizzi, K. P., Garcia, F. O., Costa, J. L., \& Picone, L. I. (2005). Soil water dynamics, physical properties and corn and wheat responses to minimum and no tillage systems in the southern Pampas of Argentina. Soil Tillage Research, 81, 57-69. https://doi.org/10.1016/j.still.2004.05.001

Fageria, N. K. (2004). Influence of dry matter and length of roots on growth of five field crops at varying soil zinc and copper levels. Journal of Plant Nutrition, 27, 1517-1523. https://doi.org/10.1081/PLN-200025995

Govaerts, B., Sayre, K. D., Lichter, K., Dendooven, L., \& Deckers, J. (2007). Influence of permanent raised bed planting and residue management on physical and chemical soil quality in rain fed maize/wheat systems. Plant Soil, 291, 39-54. https://doi.org/10.1007/s11104-006-9172-6

He, J., Kuhn, N. J., Zhang, X. M., Zhang, X. R., \& Li, H. W. (2009). Effects of 10 years of conservation tillage on soil properties and productivity in the farming-pastoral ecotoneof Inner Mongolia, China. Soil Use Management, 25, 201-209. https://doi.org/10.1111/j.1475-2743.2009.00210.x

Hobbs, P. R., Sayre, K., \& Gupta, R. (2008). The role of conservation agriculture in sustainable agriculture. Philosophical Transactions of the Royal Society, 363(1491), 543-555. https://doi.org/10.1098/ rstb.2007.2169

Huang, G. B., Chai, Q., Fang, F. X., \& Yu, A. Z. (2012). Effects of different tillage systems on soil properties root growth grain yield and water use efficiency of winter wheat (Triticum aestivum L.) in Arid Northwest China. Journal of Integrative Agriculture, 11, 1286-1296. https://doi.org/10.1016/S2095-3119(12)60125-7

Huang, G. B., Zhang, R. Z., Li, G. D., Li, L. L., Chan, K. Y., Heenan, D. P., ... Bellotti, W. D. (2008). Productivity and sustainability of a spring wheat-field pea rotation in a semi-arid environment under conventional and conservation tillage systems. Field Crops Research, 107, 43-55. https://doi.org/10.1016/ j.fcr.2007.12.011

Karunatilake, U., van Es, H. M., Schindelbeck, R. R. (2000). Soil and wheat response to plow and no-tillage after alfalfa-to-wheat conversion on a clay loam soil in New York. Soil Till. Res., 55, 31-42. https://doi.org/10.1016/S0167-1987(00)00096-9

Lampurlanés, J., Angás, P., \& Cantero-Martínez, C. (2001). Root growth: soil water content and yield of barley under different tillage systems on two soils in semiarid conditions. Field Crop Research, 69, 27-40. https://doi.org/10.1016/S0378-4290(00)00130-1

Li, C. J. (2008). Mineral nutrition of higher plant (pp. 9-10). Beijing: China Agriculture University Press. 
Linkohr, B. I., Williamson, L. C., \& Fitter, A. H. (2002). Nitrate and phosphate availability and distribution have different effects on root system architecture of Arabidopsis. Plant Journal, 29, 751-760. https://doi.org/10.1046/j.1365-313X.2002.01251.x

Mosaddeghi, M. R., Mahboubi, A. A., \& Safadoust, A. (2009). Short-term effects of tillage and manure on some soil physical properties and maize root growth in a sandy loam soil in western Iran. Soil Tillage Research, 104, 173-179. https://doi.org/10.1016/j.still.2008.10.011

Muñoz-Romero, V., Benítez-Vega, J., López-Bellido, L., \& López-Bellido, R. J. (2010). Monitoring wheat root development in a rainfed vertisol: tillage effect. European Journal of Agronomy, 33, 182-187. https://doi.org/10.1016/j.eja.2010.05.004

Robino, P., \& de Franchi, S. (1990). Wheat root system responses to different tillage techniques. Mediterranean Agriculture, 120, 180-183.

Smith, S., \& De, S. I. (2012). Root system architecture: insights from Arabidopsis and cereal crops. Philosophical Transactions of the Royal Society B, 367, 1441-1452. https://doi.org/10.1098/rstb.2011.0234

Vanessa, M. D., Johannes, A. P., Andrea, S., Loïc, P., Mathieu, J., \& Lianhai, W. (2013). Modelling root-soil interactions using three-dimensional models of root growth, architecture and function. Plant Soil, 372, 93-124. https://doi.org/10.1007/s11104-013-1769-y

Verónica, M. R., Luis, L. B., Rafael, J., \& López, B. (2011). Faba bean root growth in a Vertisol: Tillage effects. Field Crops Research, 120, 338-344. https://doi.org/10.1016/j.fcr.2010.11.008

Yeboah, S., Lamptey, S., Zhang, R., \& Li, L. L. (2017). Spring wheat-field pea rotation with tillage systems and straw retention improves soil water utilization and reduces carbon emission. Journal of Agronomy, 16, 32-39. https://doi.org/10.3923/ja.2017.32.39

Yeboah, S., Zhang, R., Cai, L., Song, M., Li, L. L., Xie, J., ... Zhang, J. (2016). Greenhouse gas emissions in a spring wheat-field pea sequence under different tillage practices in semi-arid Northwest China. Nutrient Cycling in Agroecosystems, 106, 77-91. https://doi.org/10.1007/s10705-016-9790-1

Zheng, S. H., \& Yan, C. R. (2006). The ecophysiological and morphological characteristics of maize in seedling stage under water stress. Acta Ecologica Sinica, 26(4), 1138-1143.

\section{Copyrights}

Copyright for this article is retained by the author(s), with first publication rights granted to the journal.

This is an open-access article distributed under the terms and conditions of the Creative Commons Attribution license (http://creativecommons.org/licenses/by/4.0/). 